\title{
"Open to All Classes on Terms of Perfect Equality": The Association of Mechanics' Institutes and the Establishment of "Adult" Education in Ontario, 1868-1895
}

\author{
Darren Neil Ferry \\ Nipissing University
}

\begin{abstract}
Typically, the Mechanics' Institute movement in late nineteenth-century Ontario has been described by historians as an abject failure in providing educational opportunities for young working-class adults. However, under the direction of the Association of Mechanics' Institutes of Ontario (1868-86), Mechanics' Institutes across the province were specifically designed to assist individuals from all social classes and across gender lines to upgrade educational skills that were sorely lacking. As a result, the Association of Mechanics' Institutes of Ontario was an influential and fairly effective transition instrument of the educational state, a bridge between voluntary and rather haphazard way in which education for the working classes was handled before mid-century and the complete takeover of "adult" education by the Ontario Department of Education in 1895.
\end{abstract}

RÉSUMÉ

À la fin du dix-neuvième siècle en Ontario, le mouvement des instituts mécaniques a été souvent qualifié d'échec total en terme d'opportunité de formation pour les jeunes adultes travailleurs. Cependant, sous la direction de "The Association of Mechanics' Institutes of Ontario » (1868-86), les instituts mécaniques partout dans la province ont été conçus spécifiquement pour aider des personnes de toute classe sociale et des deux sexes à améliorer leurs habiletés déficientes dans différents métiers. Par conséquent, l'Association a été un instrument valable et assez efficace de formation professionnelle. Elle fait la transition entre une instruction incomplète et peu rigoureuse offerte aux travailleurs à cette époque et l'organisation formelle de l'éducation aux adultes prise en charge par le Département de l'éducation de l'Ontario en 1895.

In 1881, Dr. Samuel May, the Superintendent of Mechanics' Institutes for the Department of Education in Ontario, released his long awaited report on the state of adult "working-class" education across the province. May's conclusion would not have surprised promoters of the Mechanics' Institute movement since the early 1830s, 
that "the education of the working classes has been sadly neglected in this Province." Alternately blaming the failure of the educational possibilities of the Institutes on a superfluous amount of state funding, institutional neglect and the introduction of "light reading" into Institute libraries, May reserved some of his harshest criticism for the Association of Mechanics' Institutes, the organization overseeing the Institute movement in Ontario since 1868. In his canvassing of Mechanics' Institute directors throughout Ontario, May concluded that "the majority of Institute officials are very decided in their opinion that the Association should be abolished." ${ }^{1}$ Not all promoters of adult education in the province agreed with May's report. Otto Klotz, the President of the Preston Mechanics' Institute, responded to May's report a few months later, and lambasted the Superintendent's findings. Very critical of May's highly uneven funding formula for Institutes across the province and for his assertion that the Ministry of Education would generate more functioning night classes, Klotz nevertheless agreed with May's final conclusion, noting that "throughout the whole "Report" there is abundant, incontrovertible and plain evidence that ....all attempts to make evening class instruction in Mechanics' Institutes if not universal at least general, have proved a failure." Klotz was even more disparaging of the Association of Mechanics' Institutes of Ontario, and noted with satisfaction that May's report discovered that many Institute directors shared a similar disdain for this organization, as he noted that "the Association will soon suffer the same fate as its predecessor, the Board of Arts and Manufactures, and be numbered among the things that once were, but were now no more. Peace be to its ashes." 2

The relative failure of Mechanics' Institutes to provide educational opportunities for the working classes has permeated not only the historiography of the Ontario Institute movement, but also many accounts of Mechanics' Institutes throughout the British Empire. With its origins in the scientific education of early nineteenthcentury artisans in Glasgow, Scotland, the Mechanics' Institute movement under the aegis of education pioneer George Birkbeck alighted in London, England, with the establishment of a Mechanics' Institute there in 1824. Birkbeck introduced a series of scientific lectures, a subscription library, and eventually oversaw the creation of evening classes to furnish London's working classes with educational opportunities that were lost during years of apprenticeship training. ${ }^{3}$ However, by the 1850 s, many contemporaries such as the patron of the London Mechanics' Institute, Henry Brougham, believed that the Institutes were neglecting the very constituency they were created to help. Historians have generally agreed with this assessment, contending that by the mid-nineteenth century the Mechanics' Institute movement was declining in both popularity and usefulness in most cities and towns throughout Great Britain. Explanations for the failure of the Institute movement to educate workingclass adults in Britain have ranged from an unwillingness of the state to financially and institutionally support these educational efforts, to the rather blatant management of Institute functions by middling-class executives bent on fostering an agenda of cultural ascendancy, hegemony and social control. ${ }^{4}$

Notwithstanding these negative portrayals of Mechanics' Institutes, more recent scholarly efforts have revisited and revised the "failure paradigm" associated with the 
Institutes and their endeavours among the working classes in Britain. The work of Martyn Walker has done much to rehabilitate the reputation of working-class education housed in the British Institutes. Walker has argued effectively that the sizeable increase of working-class members in Mechanics' Institutes and the amount of educational books circulating among Institutes in the Yorkshire region illustrate the continued relevance of Mechanics' Institutes for the working classes as late as the 1890s in Britain. ${ }^{5}$

The "failure" of the Mechanics' Institute movement to educate working-class adults has also informed much of the scholarly examination of the Institute movement in the colonial context. Although Mechanics' Institutes did recruit a sizeable working-class constituency in the early half of the century, most historians maintained that the working classes abandoned Institutes in droves by the late nineteenth century when middle-class directors were unmasked as agents of a burgeoning industrial hegemony. ${ }^{6}$ Suzanne Zeller has argued that the failure of Canadian Mechanics' Institutes to educate working-class patrons resulted from a lack of congruency between those who desired more practical, "technical" education for mechanics, and those who favoured a more theoretical scientific curriculum for the working classes. ${ }^{7}$ Even in the colonial context, interest in the Mechanics' Institute movement has reflected a renewed focus on their socio-cultural significance. These "revisionist" historians of Mechanics' Institutes contend that despite limited access to educational opportunities, the working classes managed to advance notions of artisanal self-education from within a theoretical matrix regarding societal and self-improvement found in the Institutes. ${ }^{8}$ Working-class participation in the night classes, lectures and libraries offered through these colonial Mechanics' Institutes therefore provided ample opportunities for upwards mobility and material advancement in an industrial age, while simultaneously buttressing a "liberal" social order that often harnessed education as a means of regulating and engineering consent to its governing structures. Following the pioneering work done in Australia on the geographical complexities of Mechanics' Institutes, these historians also maintain that Mechanics' Institutes became important socio-cultural expressions for all social classes in molding a sense of community so necessary to the colonial experience. ${ }^{9}$

The challenges of adult education in Ontario were indeed acute at mid-century, as the emerging educational state grappled with providing the working classes further educational opportunities. The difficulties surrounding provisions for "adult" education at this junction were compounded by the uneven delivery of educational services in toto by the Board of Education in Upper Canada itself throughout the nineteenth century. ${ }^{10}$ Despite these challenges, Mechanics' Institutes established under the Association of Mechanics' Institutes of Ontario were designed to assist individuals from all social classes and across gender lines to upgrade their educational skills. In fulfilling this mandate, the Association of Mechanics' Institutes was not unlike the Yorkshire Union of Mechanics' Institutes in England, an organization linking itself to the Society for Encouragement of Arts, Manufactures and Commerce and various other Schools of Art to address the needs of employees and employers. As Martyn Walker suggests, the success of the Yorkshire Union of 
Mechanics' Institutes rested with the social diversity of its membership base and its ability to provide educational opportunities for all members of the community. ${ }^{11}$ The Association of Mechanics' Institutes of Ontario was no different in its approach to educating adults from 1868 to 1895 ; any adult that required the additional educational services offered by Mechanics' Institutes would be encouraged to attend their evening classes, lectures and libraries. This cross-class approach was particularly effective in the colonial context, where the Industrial Revolution arrived rather late, and class structures were not as fixed as those in Great Britain. ${ }^{12}$ As a result, the Association of Mechanics' Institutes of Ontario was an influential and effective transition instrument of the educational state, a bridge between the voluntary and haphazard way in which education for the working classes was handled before midcentury, to the complete takeover of "adult" education by the Ontario Department of Education in 1895.

The early manifestations of the Mechanics' Institute movement in Upper Canada during the 1830s were rather rudimentary efforts to help working men achieve their educational goals. From libraries, to lectures, entertainments and mutual improvement classes, the centralization of education for the "operative" classes occurred in 1857 with the establishment of the Board of Arts and Manufactures of Upper Canada. Not only did the Board promote night classes within the Mechanics' Institutes, they also promoted exhibitions of skilled productions to its educational repertoire, as these spectacles welded skilled workmen to the emerging industrial state. As the Board earnestly declared, "the committee looks upon these institutes as schools or colleges of the adult mechanical or industrial classes of the community, affording them the means of instruction and healthful recreation so essential to their well-being." 13 Even under the direction of the Board of Arts and Manufactures, a different vision of education other than simply offering opportunities for skilled workmen was encouraged. As early as 1861, the Board embarked on an ambitious scheme of expanding its educational offerings within local Institutes, culminating in a central examining board in Toronto. Not only were mechanical, commercial and "practical" science classes offered to help skilled workmen with their daily tasks, but the Board suggested classes in Botany, Geography, Geology and Agriculture for the farmer, as well as rudimentary courses in History, Social Economy, English Literature, French, German and Music for the aspiring professional. ${ }^{14}$ This would foreshadow the focus of the Association regarding the Mechanics' Institutes in Ontario, that they should provide the necessary education for all social classes to achieve upwards mobility.

And this certainly was the exalted goal of the Association of Mechanics' Institutes of Ontario when it was established in 1868, to provide diverse educational opportunities towards social and economic advancement for the whole community. ${ }^{15}$ When the Minister of Agriculture and Public Works, John Carling, created the Agricultural and Arts Association, he noted that the industrial classes would have the highest claim on Mechanics' Institutes themselves. Yet Carling also envisioned an even loftier pursuit of the Association, that it would provide educational prospects for all adults who required it. He wrote: 
The deficiency has often been keenly felt and lamented by many, when placed in certain positions of life, who, either from accident or from the want of a proper appreciation of the value of learning, have failed to acquire that requisite knowledge which is one of the great guarantees of success. On this account we feel all the more lively sense of what Institutes have done in providing, at terms which place it within the means of all, instruction in the more essential branches required by the mechanic, the artizan, the clerk, and the man of business...The efforts put forth by this Institute, as a public education, have proved to be, what its name implies, a people's Institute; and have given it a fresh hold on the public for its support. ${ }^{16}$

This link with the Education Department of the province of Ontario was made even clearer in the 1872 annual report of the Association, when its Secretary, William Edwards, crowed that Mechanics' Institutes were no longer merely voluntary associations, but "public institutions, forming a part of the educational system of the province, and, as such, receiving Government aid and subject to inspection by the County Inspectors of Public Schools." 17

Local Mechanics' Institutes grappled with such pronouncements from the Association, as they attempted to provide an educational curriculum that would benefit all members within the community. In 1867, the committee placed in charge of the night classes within the Toronto Mechanics' Institute recognized that the evening classes were for the benefit of the "mechanics and the artizans, and the working classes generally," and worthy of public support. Frederick Cumberland, the noted Toronto architect and president of Toronto Mechanics' Institute, recognized the importance of all social classes and occupations participating in the night classes in an 1868 address that lauded "the advantages of a thorough commercial education, contending that the resources of this country were so great that all who wished to take advantage of the opportunities afforded for obtaining lucrative situations might easily obtain a comfortable livelihood." ${ }^{18}$ The class committee also noted with satisfaction in its 1872 report that the commercial curriculum of the Institute had done much good in the city of Toronto, as "in some of the best counting-houses may be seen youths who obtained their first lessons in accounts at the Mechanics' Institute classes." ${ }^{19}$

The executive of the London, Ontario Mechanics' Institute echoed these sentiments in its 1874 annual report, claiming that its night classes were not only about mutual improvement for young men, but also a means for them to "get ahead in business." ${ }^{20}$ Membership statistics taken from this period from both the London and the Toronto Mechanics' Institutes illustrated that the vast majority of those taking advantage of Institute activities were in fact from the upwardly mobile lower middle classes - clerks, accountants, minor merchants, shopkeepers and bookkeepers. ${ }^{21}$ As a result, the executive committee was so concerned about the "takeover" of the London Mechanics' Institute by these "commercial classes" that it pasted a clipping from a local London newspaper into the 1871 annual report, complaining that "those who generally frequent the reading rooms of Mechanics' Institutes are not mechanics at all. There is, of course, a slight sprinkling of these, but the great majority are men 
of leisure or of business, clerks, or annuitants who have little or nothing to do and who therefore take refuge from themselves and from ennui among the newspapers." 22

Despite the proliferation of lower middling-class members in Mechanics' Institutes during the latter half of the nineteenth century, there was still a sizeable workingclass constituency which continued to faithfully attend Mechanics' Institutes. ${ }^{23} \mathrm{With}$ these statistics in mind, expanding the educational mandate of Mechanics' Institutes to include "adults" of all social classes and occupations became a major theme of the Association of Mechanics' Institutes of Ontario during its prize essay contest in 1876. Based on the topic "Mechanics' Institutes and how to Improve them," the contest was theoretically opened to all interested parties throughout Ontario. The middle-class nature of this enterprise and its connection with the educational state was evident from the outset, as over half of the respondents were schoolteachers, school inspectors, or Mechanics' Institute officers, despite some moderate workingclass participation. Given that one of the judges of the contest was the noted liberal Goldwin Smith, the ideological purity of liberal self-improvement and progress contained within the prize-winning essays would also be ensured. ${ }^{24}$ Many of the essayists continued to grapple with an outmoded working-class educational paradigm, as a significant number of writers noted that Institutes should function primarily as night classes for working-class patrons. In fact, most of the essays submitted to the Association echoed what Ian Scott, the librarian of the Clinton Institute wrote, that Mechanics' Institutes were "especially designed for the benefit of the working classes" and as such, was deserving of public support. ${ }^{25}$ E.D. Platt, a school inspector from Picton, Ontario, added that Institutes should also provide the "industrial classes" with a sense of upward mobility, as he called on "the toiling mechanics" to understand that "the higher the degree of mental ingenuity and ripe thought they can impress upon their handiwork, the surer the passport to a high place of success in their chosen profession." 26

Coinciding with the largely middle-class nature of the essay writers, many suggested that night classes would not only educate the working classes, but they would also keep skilled workmen from becoming idle wastrels. The Reverend John Butler, a professor at the University of Toronto, argued that lectures, night classes and all Institute activities needed to be "conducive to the improvement of man's better nature, to his mental, moral or social progress." As a result, the reading rooms and libraries of local Institutes had to be "at least" as attractive to the operative classes as the nearby saloon. ${ }^{27} \mathrm{~J}$. Pennington Macpherson, a clerk from Ottawa, claimed that Institute classes would assist young men in avoiding trouble, for "at the weakest period of their lives, [they] are thrown into the temptations of a city, without the comforts of a home, and deprived of the control and beneficial experience of kind and careful parents and become subject to the influence and contaminating example of evil companions." 28 Even some skilled workmen concurred with this assessment: W.A. Walls, a millwright from Otterville, stated that the evening classes in local Mechanics' Institutes would draw away working-class youth from the dangers of saloons and billiard tables, as "time is too valuable to be killed." If the young men availed themselves of the educational and intellectual feasts available at the local 
Mechanics' Institute, claimed Walls, they "must be brought into healthful activity; otherwise sloth and selfishness will deaden all the best feelings of human nature." ${ }^{29}$

Despite this fascination with the education of the working classes, many essayists were involved with the same level of debate as the Association of Mechanics' Institutes themselves regarding their educational mandate. Even though most essays agreed that the Institutes should exist primarily for the education of working-class adults, they noted that the Institutes should also benefit others within the community whose education was lacking. Frederick Dickson, a signal officer from Goderich, wanted Mechanics' Institutes to increase their offerings in the various night classes to appeal to all social groups and occupations within the community, "by offering all the inducements in its power, by showing itself actively striving for the benefit of the public and by drawing in all classes thereof to participate in its privileges, [then] its prominence is established and it becomes the popular institution." ${ }^{30}$ Thomas Davison, President of the Toronto Mechanics' Institute and eventual winner of the essay contest, claimed that "Institutes are for the public good, irrespective of creed, class or colour, and only require a proper representation of their claims to meet with the hearty support of every right thinking citizen." 31

J. Pennington Macpherson mused in his essay whether or not a name change for Mechanics' Institutes was in order, given that the vast majority of Institute members were taken from occupations other than skilled workmen, namely, "the professional men, merchants, architects, shopkeepers and clerks." ${ }^{2} 2$ Ian Scott, the librarian of the Clinton Mechanics' Institute, went even further when he suggested that the Institutes were a supplement to the provincial education system, and as its "adult" arm municipalities should freely give Mechanics' Institutes revenue grants as "an extension of the public schools." ${ }^{3}$ David Boyle, Elora's famous "artisan archeologist," who personified the importance of working-class educational opportunities, echoed these sentiments in his essay. While calling for workingmen to be more involved in the teaching of "practical science" in Institute classes, Boyle also wrote that Mechanics' Institutes should provide inter-class opportunities for educational instruction. To Boyle, "when farmers, bookkeepers, and professional men are members of an Institute, their tastes and interests ought to be regarded not only in the selection of books and papers, but also in the management of classes.... the employer, mechanic, apprentice, laborer, shop-woman, sewing girl, clerk, farmer and professional, should all be made interested parties." 34

David Boyle added the possibility of a gendered component to the Institute evening classes, as there were "scores of hundreds of sewing girls and servant maids to be met with in every town... When we consider also the low rate of remuneration at which most females are paid, it would perhaps be wise to admit working women at reduced rates." 35 Some of the more middle-class essay writers offered a caution to Boyle's enthusiasm for instructing women in Mechanics' Institutes. Fredrick Dickson noted that women should only be taught specific subjects fitting for their station in life: "Domestic economy should be the chief feature of the studies brought under their notice, and a female class for discussing subjects pertaining to their position in the world and society would be productive of benefits although I confess it would 
be a difficult task to start such an organization." 36 On the surface, Richard Lewis's second-prize winning essay lauded the Institutes for opening up the night classes to working-class women. To Lewis, the night classes "were designed for women as well as men," as "the competition arising from the two sexes studying together would have the best effect on their educational progress." ${ }^{37}$ Yet Lewis also condescendingly remarked that "union of the two sexes give an attraction to every assembly... and cannot fail to be advantageous to the success of the classes," while also conceding that the bookkeeping classes should only help women with domestic economy and "household expenditures," instead of landing working-class women employment as bookkeepers, clerks or accountants. ${ }^{38}$

As a result of the good advice provided by the Association's essay contest, Mechanics' Institutes in Ontario would indeed open their doors to all members of the community who felt their educational opportunities lacking. Given the educational wrangling over establishing the secondary school system in Ontario throughout the 1870s, "adult" education found in Ontario Mechanics' Institutes essentially could begin with any youth around fifteen or sixteen years of age. In fact, one of the few Institutes that kept statistics of its evening classes during the 1870s, the Toronto Mechanics' Institute, confirms this nature of adult education. Out of the 617 students enrolled between 1877 and 1880 in Toronto Institute classes, nearly 65\% of the total student body was under 18 years of age. While the curriculum for this group of young students included such "core" subjects as grammar and arithmetic, there was also a healthy dose of commercial education classes benefitting aspiring middle-class individuals such as bookkeeping, architectural and mechanical drawing, phonetic shorthand and telegraph operation. ${ }^{39}$

Even small-town Mechanics' Institutes in Peterborough and Barrie experimented with offering commercial classes for young, upwardly mobile students. Not only did the Barrie Mechanics' Institute in 1879 recommend classes in mechanical and model drawing, it also hired a teacher to present a class on "general business instruction." ${ }^{40} \mathrm{~A}$ printed broadside from the Peterborough Mechanics' Institute advertising the night classes noted that "it is expected that a sufficient number of young men, desirous of improving themselves intellectually and fitting them for positions in the business world," would be attending classes in the Peterborough Institute. ${ }^{41}$ Not only would this commercial curriculum benefit those in the rising "middle-class" professions of clerking, bookkeeping and accountancy as well as the industrial working classes, the iconic "self-made entrepreneurs" - perceived by many as forming the backbone of the Ontario economy - might also attend to improve their business acumen. ${ }^{42}$

Mechanics' Institutes also took very seriously the proposal to offer more educational opportunities to young women during the 1870 s. While it is unfortunate that the class committee of the Toronto Mechanics' Institute did not keep occupational statistics of their students, they did manage to record evening class statistics based on both age and gender. Over the same period discussed above, from 1877 to 1880, over $11 \%$ of all Toronto Mechanics' Institute evening class students were young women. ${ }^{43}$ Coupled with the statistics on age, this suggests that some Institutes invited domestic servants, "sewing girls" and other working-class women to join the evening classes. At 
the very least, this suggests that young women were taking advantage of Mechanics' Institutes in order to complete their education alongside the young men. George Shaw, the President of the Peterborough Mechanics' Institute, was charged by his class committee to encourage female participation in the evening classes during their annual meeting. To both Shaw and the committee, "while we are making efforts to educate the young mechanic we have forgotten the mechanic's wife. The mechanic's wife is to a great extent the businessman for the family; she deserves a good rudimentary business education, a thing which would never be amiss but often wonderfully helpful in every man's wife." ${ }^{4}$ While Shaw was obviously pandering to more masculine notions of female domesticity, his statements could be construed as a need for women to assist their husbands or fathers to keep accounts in the family business, or even to become entrepreneurs themselves. ${ }^{45}$

With all of these major changes to Institute evening classes, the responsibility for overseeing the Association of Mechanics' Institutes of Ontario came to rest with the provincial Department of Education in 1880. After the 1880 annual meeting of the Association, the executive printed the speech of its President James Young, forwarding it to all member institutes throughout Ontario. Responding firmly to the circulating rumours of Dr. May's rather unfavourable report on Institute evening classes, Young went on the offensive in his "published" remarks. Countering the claim that mechanics were nowhere to be found in Mechanics' Institutes, Young stated that "the number of the industrial classes to be found among the officers and members of the various Institutes, so far as my observation extends, is a very considerable portion of the whole." However, in the very next sentence, Young illuminated the expanded vision of the Association for the Mechanics' Institute movement, telling delegates that "it is a mistake to suppose that the Institutes were created for one class of the community alone; and in the interest of these institutions, and even of the mechanical classes themselves, it is of the utmost importance, in consideration of the consequently limited constituency in each community from which they can draw support, that Mechanics' Institutes should continue to be open to all classes on terms of perfect equality." 46

As a result, the mandate to provide "adult" education for all of Ontario's youth regardless of age, gender or occupation continued to be preached by Association executives. What is interesting about the Association of Mechanics' Institutes after their absorption by the Ontario Department of Education, is that the Association actually saw an increase in attendance in the evening classes of member Institutes during the years 1881 to 1886 . The statistics drawn from these evening classes also illustrate the importance of the Association focusing on the need for inter-class upward mobility, with the establishment of the "commercial" division of evening classes. Apart from the years 1885 and 1886, which clearly were anomalies, given that well over half of the total students in Ontario Mechanics' Institutes attended classes in drawing in order to achieve certification in art proficiency, the vast majority of students attended classes of the new commercial curriculum. Of the more than 7400 students attending evening classes in the years 1881-1884, nearly $70 \%$ of them took commercial classes in writing, bookkeeping and arithmetic. As mentioned, the next largest attendance 
came in the art classes, and then the "primary" division of English, composition and elocution classes - for those "adult" students who were unable to finish their elementary education. By far the least attended classes were those in the "technical" division of mechanics, engineering and telegraphy during these years, providing more ammunition to critics that the "failure" of the Mechanics' Institutes did rest at times with the non-participation of the industrial classes. ${ }^{47}$

Despite the enthusiasm of the Association for the expansion of the commercial classes and the education of the upwardly mobile, there were some dark clouds over the horizon. The two most prosperous Mechanics' Institutes in the province of Ontario, the Hamilton and Toronto Mechanics' Institutes, would succumb in short order to the seduction of the Free Library movement in the 1880s. These "free" libraries would be supported by a general rate similar to education rates levied to the municipal taxpayer, as opposed to fees charged to individual Mechanics' Institute members. The attraction of the free library system to large urban areas in Ontario was simple; a stronger and more extensive tax base meant more books and better services. ${ }^{48}$ Similarly, the establishment of the Ontario School of Art in Toronto would "draw" away students from the various Institute art classes. Despite the record high of nearly 2500 art students from 1885 to 1886 in Institute drawing classes in the Association, this number would be halved in 1887 , and then halved again on average every year until $1895 .^{49}$

Perhaps the greatest impediment to the education of the working classes in technical evening classes was the attitude manifested by both the Association and from the Ontario Department of Education. On the surface, Dr. May's report on the evening classes of Mechanics' Institutes focused on the education of the working classes and how "the mechanics of Canada have as much original genius and natural talent as is to be found in any country in the world, and all that they require is to be taught the principles of the arts and sciences on which the manufacturing processes depend." And yet May also condescendingly stated that he wanted to do away with the system of cash prizes to workmen taking Institute night classes, as instituting a simple grading system would offer "proof of his honesty, sobriety, intelligence, and industry, by which his pecuniary position might be benefitted." ${ }^{0}$ William Edwards, the secretary of the Association, likewise stated in the seventeenth annual report that Institute night classes in the technical division needed to function as an auxiliary to the Ontario School of Science, as the Institute drawing classes were to the Ontario School of Art. In this fashion, argued Edwards, the technical classes would be "classes for the study of the principles of mechanics, [and] chemistry as applied to the mechanical and manufacturing arts." ${ }^{51}$ However, Edwards also added the following missive about the education of workmen in the annual report, illustrating the staunchly middle-class nature of the executive directors, as he noted that "through the opportunities and influences connected with a well-equipped Institute, many may be kept from drifting away and leading lives of uselessness and crime, and their minds be directed to nobler aims, and they become more intelligent and better workmen and members of society." 52

Despite these challenges, directors of the Association of Mechanics' Institutes of Ontario were obviously well-pleased with the inter-class educational offerings of the 
Institute night classes for the upwardly mobile. The overall purpose of the evening classes held in Mechanics' Institutes was made even clearer in a letter written by the Ontario Minister of Education, George Ross, which was sent to all Institutes united with the Association in September of 1886. To Ross, the evening classes were the most important function of the Mechanics' Institute movement and a significant institution for those looking to "bettering themselves," as he highlighted "the importance of placing within the reach of all our young men and women the advantages to be derived from the formation of Evening Classes... [as] they would furnish facilities for mental culture to those who, in early years, were not favoured with the advantages of a liberal education. With a little effort on the part of the Directors, I feel confident Mechanics' Institutes might be made a powerful auxiliary of our school system. ${ }^{53}$ What is significant about Ross's letter is the vision contained within it - that the Mechanics' Institutes were not only part of the Ontario system of education, they were also a key component of the educational state.

Just a few days after the publication of Ross's circular to member Mechanics' Institutes, came news of the dissolution of the Association of Mechanics' Institutes of Ontario. ${ }^{54}$ Unlike the Board of Arts and Manufactures of Upper Canada, the Association disbanded not with a bang, but with a whimper. While some regret was expressed at the last official meeting of the Association that the government was abandoning their organization, evidently the executive felt that the Ontario Department of Education was fulfilling its mandate when it came to promoting Institute evening classes across the province. With such a vision in mind, the gradual disbanding of the Association of Mechanics' Institutes was no catastrophe. In fact, successive Ministers of Education in Ontario recognized the continuing importance of Mechanics' Institutes in providing "adult" education throughout the province, as the number of chartered Mechanics' Institutes actually grew after 1886, from over 100 in that year to a high of 311 Institutes across Ontario by $1895 .{ }^{55}$ Of more significance, even after the disappearance of Mechanics' Institute art students to the new Ontario School of Art by 1886, the number of attendees taking Mechanics' Institute classes remained relatively stable from 1887 to 1895 . A couple of factors are at play with these statistics - one is that only large urban Mechanics' Institutes such as those in Toronto, Hamilton and London would turn into Free Libraries by the 1890s. Many chartered Institutes that emerged after 1886 were established in small to mid-sized towns and villages, where educational opportunities were few and far between. ${ }^{56}$

The most important factor increasing "adult" evening class participation in Mechanics' Institutes was the continuing need of various students to improve their earning potential through educational opportunities offered in the Institutes. The statistics also bear this out - from 1887 to 1895 , a total of some 12,500 students attended Mechanics' Institute classes in the province of Ontario. ${ }^{57}$ The commercial classes remained a major draw, as $62 \%$ of all students attended these classes, which were also expanded to teach subjects essential to the new industrial economy such as typing and commercial law. Institute drawing classes likewise remained a major component of Mechanics' Institute education despite the attraction of the Ontario School of Art in Toronto, although technical education for the industrial working 
classes continued to lag well behind in terms of attendance. In fact, not one student between 1885 and 1895 enrolled in a Mechanics' Institute technical division evening class in the province of Ontario. ${ }^{58}$

This is not to say that the Department of Education was uninterested in the education of the working classes in their management of the Mechanics' Institutes. In 1887, Education Minister Ross sent Alexander Manning on a fact-finding mission to Great Britain on the state of Mechanics' Institute classes there. Manning's report was very favourable towards the Institute movement in England, noting that the only thing lacking in the Ontario Mechanics' Institutes in comparison was "the active co-operation of the leading men in the various localities, and the support of the large employers of labour." In regards to the night schools in Great Britain, Manning reported that the classes were full of both young male industrial workers and young women, and were highly successful in bringing education to the working classes. Even more startling was Manning's conclusion, that the Ontario Department of Education "MUST have FREE night schools." 59 While Manning's proposal for "free" night schools was not adopted by the Ministry of Education at this point in time, the concept of offering "adult" education as the elementary system did for youth and children would inform the debate over technical education taking place in the Ministry of Education during the 1890s and beyond. ${ }^{60}$

Even though the Ministry of Education continued to view Mechanics' Institutes as a vehicle for the improvement of the working classes, the universal nature of the curriculum definitely appealed to a wide variety of social groups. The limited occupational evidence available suggests that many attendees of Mechanics' Institute commercial classes from the years 1886-1891 came from assorted backgrounds. While most Mechanics' Institute reports did not record occupations or age in their reports to the Ontario Ministry of Education, such information can be derived from those communities that did. Ranging from fairly large towns such as Kingston and Peterborough, to moderately-sized towns like Paris and Scarborough, to small villages such as Hespeler and Midland, these statistics do tell an interesting story (see Table 1). Not unlike the results of the evening classes held in the Toronto Mechanics' Institute some twenty years earlier, the average age of the students attending commercial classes where both age and occupation have been recorded was around 17 years of age. Of even more interest in this survey is the occupational diversity of students in the evening classes of these Institutes. Young male working-class students were very well-represented in this sample, making up nearly $40 \%$ of the total evening class participants. Occupations among this working-class constituency ranged from machinists, carpenters, blacksmiths and apprentices, to pattern makers and "delivery boys" (Table 1). It is likely that this group of students joined the evening classes to shore up their neglected educational opportunities as well as to upgrade their skills for material advancement. ${ }^{61}$

Additionally, nearly $30 \%$ of the student population in Mechanics' Institute evening classes came from families in the lower middling strata of society, with students listing such occupations as clerks, bookkeepers, architects, druggists and florists in the rolls of the commercial classes. Another $14 \%$ of the student body taking a 
commercial curriculum came from the agricultural portion of the community, with farmers dominating the Scarborough evening commercial class to a tune of $17 \mathrm{stu}-$ dents out of the 18 who attended (Table 1). Clearly these students wanted to upgrade their skills suitable for employment, or to assist with their own business/entrepreneurial planning for whatever sphere of business or agricultural activity they were engaged in. ${ }^{62}$ A full $15 \%$ of Institute students in the various commercial classes were young women. Evidently some Institutes took rather seriously David Boyle's call for

Table 1

Occupations of "Commercial” Evening Class Attendees of Mechanics' Institutes in Selected Ontario Towns, 1886-91

\begin{tabular}{|c|c|c|c|c|c|}
\hline Occupation & Total & $\%$ & Occupation & Total & $\%$ \\
\hline Machinist & 22 & & Mill worker & 15 & \\
\hline Pattern maker & 10 & & "Living at home" & 3 & \\
\hline Carpenter & 5 & & Cashier & 3 & \\
\hline Needle maker & 4 & & Domestic servant & 2 & \\
\hline Cabinet maker & 3 & & Seamstress & 2 & \\
\hline Mechanic & 3 & & Tailoress & 2 & \\
\hline Apprentice & 3 & & "Lady" & 1 & \\
\hline Others* & 24 & & Total Women & 28 & $15 \%$ \\
\hline Total Working-Class & 74 & $39 \%$ & Druggist & 3 & \\
\hline Clerk & 35 & & Florist & 3 & \\
\hline Bookkeeper & 6 & & Tailor & 2 & \\
\hline Total Clerical & 41 & $22 \%$ & Others*** & 4 & \\
\hline Others** & 4 & & Total Business & 12 & $8 \%$ \\
\hline \multirow[t]{3}{*}{ Total Professional } & 4 & $2 \%$ & Farmers & 26 & \\
\hline & & & Teamster & 1 & \\
\hline & & & Total Agricultural & 27 & $14 \%$ \\
\hline
\end{tabular}

NOTES: The following listing of the attendees of Mechanics' Institutes commercial class are taken from the Paris, Midland, Kingston, Hespeler, Peterborough and Scarborough Institutes.

* Other occupations in the "working-class" category include: printer, tinsmith, packer, carder, weaver, wool sorter, sock spinner, knitter, train engineer, fireman, steamboat engineer, express messenger, delivery boy, stonecutter and labourer.

** Other occupations in the "professional" category include: telegrapher, photographer and architect.

*** Other occupations in the "business" category include: milk vendor, jeweller, tailor, and butcher.

SOURCE: Ministry of Education files, AO, MS 5635, RG 2-42-0-2306 to RG 2-42-0-2372 and the Peterborough Mechanics' Institute fonds, NLA, series C2, class committee reports, C2:f:13, report of the 1886 commercial class, 23 April 1886. 
more participation in Institute classes for young working-class women, as three-quarters of the young women attending Institute classes according to these statistics were either "mill girls," domestic servants or seamstresses (Table 1). Young middle-class girls could also attend evening classes in the local Mechanics' Institute, as attested by the listing of cashiers, "ladies" and the infamous occupational category "those who stay at home" appearing on the rolls of Institute classes. Whatever their position in society, young women could attend evening classes in the local Mechanics' Institute to offset educational neglect or to provide similar opportunities for material advancement as the young men. ${ }^{63}$

The theme of educational opportunities in Mechanics' Institutes providing material advancement for attendees across the social strata appeared in advertisement broadsides of various Mechanics' Institutes and their evening classes as late as 1895 . For example, the motto of the commercial classes designed by the executive of the Peterborough Mechanics' Institute was "Learn More to Earn More," with the added proviso in the evening classes, "every effort will be made to help all students." The broadside also attempted to draw in upwardly mobile working-class pupils to their commercial classes, as the directors noted that "no mechanic needs stay away from the class because of his lack of education, as the classes are for the purpose of assisting those who desire to better themselves." 64

The year 1895 is significant for adult education in Ontario, as Mechanics' Institutes were officially legislated out of existence when the public library movement essentially took over the assets of Institutes across the province. As part of the 1895 Act regarding public libraries, the Department of Education reserved the right to regulate "qualified" teachers, learning materials and even the curriculum necessary for the function of the adult night classes as part of the provincial school system. The Department also provided a maximum \$100 grant for any public library offering evening classes to interested parties. Unfortunately, the Ministry of Education in Ontario discovered as late as 1900 that the vast majority of municipal library boards did not undertake either evening classes or technical instruction. ${ }^{65}$ The most substantial evolution in "adult" education in Ontario came with the expansion of the high school system and a renewed interest in technical education throughout the province. Between 1883 and 1904 the number of students in Ontario secondary schools more than doubled, which encouraged teenagers aged 15-17 to remain longer in school. Similarly, the nature of vocational training in secondary schools changed with the passing of the Industrial Education Act in 1911, establishing two-year general industrial schools, and technical departments or technical schools within the existing schools system. These events significantly limited policy discussions in the Ontario government regarding "adult" students and provisions for their education by the First World War. ${ }^{66}$

While many students benefitted from the commercial division of evening instruction in rural and small-town Mechanics' Institutes and through the expansion of the secondary school system during this period, technical education solely for the use of working-class adults in Ontario floundered by the turn of the century. An instructive example is the aborted attempt by fourteen carpenters associated with the 
United Brotherhood of Carpenters and Joiners of America to establish a Technical Library in the city of Ottawa in 1901. Following the lead of the Trades and Labour Congress which called on the Ontario government to establish technical schools, the petitioners of the Ottawa Technical Library offered the following resolution; "the development of Canadian industries and the extension of our trade abroad makes it imperative that our native population should be more thoroughly trained in the arts and sciences underlying the theory and practice of our trades and manufactures." ${ }^{67}$ In establishing the Technical Library and evening technical classes, the petitioners were fairly confident that they would qualify for a grant under the Ontario Department of Education. However, no grant was forthcoming, and S.E. Cross, the secretary of the Technical Library, expressed his disappointment to the Department of Education in no uncertain terms: "We cannot understand why Ottawa should be deprived of the privilege of conducting classes and having a library and receiving the Provincial Grant, just because there was some years ago a Mechanics' Institute here. We are prepared to carry out the requirements of the act and do not see why we should have to wait until Carnegie or someone else establishes a Free Library here to get the books we require." Perhaps it was the Library's affiliation with the Carpenters and Joiners Union, boldly proclaimed on union letterhead, which provoked the Department's reticence to award the grant. Or the Department's refusal to award the grant could be based on Cross's combative tone, when he concluded the letter with the following complaint: "We believe that when the labour men and others are now willing to organize according to the Act and conduct their business to your satisfaction, you should accord them the grant, and when satisfied that they are able to conduct their own business, should give them possession of the books of the Old Mechanics' Institute." 68

What this study of the Association of Mechanics' Institutes in Ontario has illustrated is a different perspective on exactly how the Association was supposed to operate in providing educational opportunities for young adults, and revisiting the paradigm that Mechanics' Institutes were an obvious "failure" in providing those opportunities for Ontario's adult working classes. Even though many students did benefit from a focus on upward mobility and material advancement in Institute evening classes, the Association of Mechanics' Institutes of Ontario and later the provincial Department of Education anticipated and mandated that the evening classes offered in Mechanics' Institutes across the province should benefit all social classes of either gender within the wider community. In that light, the Association of Mechanics' Institutes of Ontario was an effective and influential transition instrument of the educational state, as its members provided "adult" educational opportunities to all who found their previous educational experiences wanting. To these promoters of adult education, the true failure of the province's Mechanics' Institutes lay in convincing the Ontario government to unreservedly sponsor their educational ventures with funding, materials and institutionalized support, and also to convince the public at large to patronize their services. 


\section{Notes}

1 Samuel May, Special Report of the Minister of Education on the Mechanics' Institutes of Ontario, (Toronto: C. Blackett Robinson, 1881), 38-40, 62-63 and 68.

2 Otto Klotz, A Review of the Special Report of the Minister of Education of the Mechanics' Institutes of Ontario, (Toronto: Willing and Williamson, 1881), 5-6, 8-9, 11.

3 On the early history of the Mechanics' Institute movement in Great Britain, see Mabel Tylecote, The Mechanics' Institutes of Lancashire and Yorkshire Before 1851, (Manchester: Manchester University Press, 1951), chapters 1 and 2.

4 For the "failure" of Mechanics' Institutes in Britain, see Edward Royle, "Mechanics' Institutes and the Working Classes, 1840-1860," The Historical Journal 14, (1971): 305-21; Steven Shapin and Barry Barnes, "Science, Nature and Control: Interpreting Mechanics' Institutes," Studies in Social Science 7, (1977): 31-74 and the collection of essays by Ian Inkster, Scientific Culture and Urbanization in Industrializing Britain, (Aldershot: Galliard, 1997). For a summary of the debate, see Martyn Walker, "Earnest Students Anxious to Acquire a Practical Knowledge Suited to the Trade of the District: The Growth and Development of the Mechanics' Institute Movement with Particular Reference to Huddersfield, 1824-1890," Journal of Educational Administration and History 46, no. 1, (January 2014): 38-40.

5 See Martyn Walker, "Encouragement of Sound Education Among the Working Classes: Mechanics' Institutes and Working-Class Membership, 1838-1881," Educational Studies 39, no. 2, (May 2012): 142-155 and "For the Last Many Years in England Everybody Has Been Educating the People, but They Have Forgotten to Find Them Any Books: The Mechanics' Institutes' Library Movement and its Contribution to Working-Class Adult Education During the Nineteenth Century," Library \& Information History 29, no. 4, (November 2013): 272-86.

6 For this literature see Foster Vernon, "The Development of Adult Education in Ontario in the $19^{\text {th }}$ Century," (EdD diss., University of Toronto, 1969); Patrick Keane, "A Study in Early Problems and Policies in Early Adult Education: The Halifax Mechanics' Institute," Social History/Histoire Sociale 8, no. 16, (November 1975): 255-74 and Nora Robins, "Useful Education for the Workingman: The Montreal Mechanics' Institute, 1828-1870," in Michael Welton, editor, Knowledge for the People: The Struggle for Adult Learning in English Speaking Canada, 1828-1973, (Toronto: OISE Press, 1987), 20-34. For Mechanics' Institutes as a vehicle for middle-class hegemony and state formation see Bruce Curtis, "'Littery Meritt', Useful Knowledge, and the Organization of Township Libraries in Canada West, 1840-60," Ontario History 78, no. 4, (December 1986): 285-311; Martin Hewitt, "Science as Spectacle: Popular Scientific Culture in St. John, New Brunswick, 1830-1850," Acadiensis 18, no. 1, (Autumn 1988): 91-119; Elsbeth Heaman, The Inglorious Arts of Peace: Exhibitions in Canadian Society During the Nineteenth Century, (Toronto: University of Toronto Press, 1999), 3-20 and Andrew Holman, A Sense of Their Duty: Middle-Class Formation in Victorian Ontario Towns (Montreal and Kingston: McGill-Queen's University Press, 2000), 105-29.

7 Suzanne Zeller, "Roads Not Taken: Victorian Science, Technical Education, and Canadian Schools, 1844-1913," Historical Studies in Education 12, no. 1/2, (2000): $1-28$.

8 Martin Hewitt, "Science, Popular Culture and the Producer Alliance in Saint John, N.B.," in Paul A Bogaard, ed., Profiles of Science and Society in the Maritimes Prior to 1914, (Victoria: Morriss Printing, 1990), 243-75; Ellen Ramsay, "Art and Industrial Society: The Role of the Toronto Mechanics' Institute in the Promotion of Art, 18311883," Labour/Le Travail 43 (Spring 1999): 71-103 and Darren Ferry, “The Original Idea Has Been Considerably Amplified: Culture, Authority, and the Emergence of a Liberal Social Order in the Central Canadian Mechanics' Institute Movement, 1828-60," in Nancy Christie, editor, Transatlantic Subjects: Ideas, Institutions and 
Social Experience in British North America, (Montreal and Kingston: McGill-Queen's University Press 2008), 439-74. For a British example of this historiography, see Jonathan Rose, The Intellectual Life of the British Working Classes, (New Haven and London: Yale University Press, 2001), 58-91.

9 The significance of rural Institutes in contrast to their urban experience is examined in Darren Ferry, Uniting in Measures of Common Good: The Construction of Liberal Identities in Central Canada, (Montreal and Kingston: McGill-Queen's University Press, 2008), 20-94. Similar debates abound regarding the Institutes in colonial Australia; see the collection of essays in Philip Candy and John Laurent, editors, Pioneering Culture: Mechanics' Institutes and Schools of Arts in Australia, (Adelaide: Auslib Press, 1994) and Buildings, Books and Beyond: Mechanics' Worldwide Conference 2004, (Victoria: Prahran Mechanics' Institute Press, 2004). For the notion that the educational state and Mechanics' Institutes formed the basis of a governing "liberal" social order, see Bruce Curtis, Building the Educational State: Canada West, 1836-1871, (London: Althouse Press, 1988) and Ferry, Uniting in Measures of Common Good, 20-94. That Mechanics' Institutes served skilled craftsmen in their quest for material elevation in a developing industrial economy see Robert Kristofferson, Craft Capitalism: Craftworkers and Early Industrialization in Hamilton, Ontario, 1840-1872, (Toronto: University of Toronto Press, 2007), 160-200.

10 See the work of Alison Prentice, The School Promoters: Education and Social Class in Mid-Nineteenth Century Upper Canada, (Toronto: McClelland and Stewart, 1977); Alison Prentice and Susan Houston, Schooling and Scholars in Nineteenth-Century Ontario, (Toronto: University of Toronto Press, 1988) and Curtis, Building the Educational State.

11 See Martyn Walker, "The Yorkshire Union Has Grown to the Most Extensive Educational Confederation in the Kingdom: The Growth and Distribution of the Yorkshire Union of Mechanics' Institutes, 1838-1890," Australian Library Journal 62, no. 2, (July 2013): 125-39 and Walker, "Encouragement of Sound Education," 152-54.

12 For the lateness of the Industrial Revolution and fluidity of class structures in industrializing Ontario, see the argument throughout Kristofferson, Craft Capitalism.

13 See the Board of Arts and Manufactures of Upper Canada fonds, (hereafter BAM), Archives of Ontario (hereafter AO), MU 279, minute book, 1857-1867, 14 January 1862. For the relationship of the Board of Arts and Manufactures, Mechanics' Institutes and the emerging industrial state, see Ferry, Uniting in Measures of Common Good, 35-39.

14 BAM, AO, MU 279, minute book, 1857-1867, 14 January and 22 January 1862.

15 As noted, this "social diversity" was the stated goal of the Yorkshire Union of Mechanics' Institutes in England; see Walker, "The Yorkshire Union Has Grown," 126-28.

16 Association of Mechanics' Institutes of Ontario fonds (hereafter AMIO), AO, MU 2021, vol. 1, annual reports, first annual meeting of the Association, 6 October 1869, 217-18.

17 AMIO, AO, MU 2021, vol. 1, annual reports, fourth annual meeting of the Association, 21 October 1872, 4. Thomas Davison, the President of the Toronto Mechanics' Institute echoed these sentiments in a letter sent to the Association; see AMIO, AO, MU2021, vol. 1, annual reports, seventh annual meeting, 23 September $1875,4$.

18 Toronto Mechanics' Institute fonds (hereafter TMI), Metropolitan Toronto Reference Library (hereafter MTL), L1, series D, vol. 24, Library, Class and Lecture Committee minutes, 11 April 1867.

19 See the TMI, MTL, L1, series D, vol. 24, Library, Class and Lecture Committee minutes, 3 April 1872.

20 London Mechanics' Institute fonds (hereafter LMI), London Public Library (hereafter LPL), vol. 4, minute book, 1871-76, 1874 annual report. 
21 Statistics taken from the Toronto Mechanics' Institute indicate that nearly $65 \%$ of all Institute members from 1876-1883 came from the clerking/accountant/bookkeeping profession, or were engaged in commercial activity; see Ferry, Uniting in Measures of Common Good, 46-7. Comparable statistics for the London Institute can be found in William Judd, ed., Minutes of the London Mechanics' Institute, (London: London Public Library, 1976), 65-71.

22 LMI, LPL, vol. 4, minute book, 1871-76, 1871 annual report.

23 Nearly $18 \%$ of the members of the Toronto Mechanics' Institute between the years 1876-1883 were from the working classes; comparable statistics can be found in the London and Hamilton Mechanics' Institutes. See Ferry, Uniting in Measures of Common Good, 46-7; Judd, Minutes of the London Institute, 65-71 and Kristofferson, Craft Capitalism, 160-99.

24 Goldwin Smith took an active interest in the Mechanics' Institute movement; see his lecture "The Labour Movement," Lectures and Essays, (Toronto: Hunter and Rose, 1881), 126-39. On the connection of "improvement" to liberal doctrines, see Daniel Samson, The Spirit of Industry and Improvement. Liberal Government and RuralIndustrial Society, Nova Scotia, 1790-1862, (Montreal and Kingston: McGill-Queen's University Press, 2008).

25 AMIO, AO, MU 2021, prize essay contest folder, Ian Scott, "Pro bono publico," 1-2.

26 See the AMIO, AO, MU 2021, prize essay contest folder, E.D. Platt, "Archimedes," 2-5 and W.D. Stark, "Labor omnia vincit," 3-7.

27 AMIO, AO, MU 2021, prize essay contest folder, Rev. John Butler, "Union is Strength," 19-21, 25-7. This rhetoric would mirror similar statements by middle-class school promoters throughout the century; see Prentice, The School Promoters.

28 AMIO, AO, MU 2021, prize essay contest folder, J. Pennington Macpherson, "Perserverantia omnia vincit," 12-14.

29 AMIO, AO, MU 2021, prize essay contest folder, W.A. Walls, "Tell me not in mournful numbers, Life is but an empty dream," 12-13.

30 AMIO, AO, MU 2021, prize essay contest folder, Frederick Dickson, "Rex," 4.

31 Both essays were published by the Association in pamphlet form; see Mechanics' Institutes and the Best Means of Improving Them: Prize Essays, (Toronto: Hunter and Rose, 1877), 4.

32 AMIO, AO, MU 2021, prize essay contest folder, J. Pennington Macpherson, "Perserverantia omnia vincit," 1-2.

33 See the AMIO, AO, MU 2021, prize essay contest folder, Ian Scott, "Pro bono publico," 4-5 and J.P. Donald, "Perseverance is better than talent," 1-2.

34 AMIO, AO, MU 2021, prize essay contest folder, David Boyle, "Arole," 13.

35 AMIO, AO, MU 2021, prize essay contest folder, David Boyle, "Arole," 13-14.

36 AMIO, AO, MU 2021, prize essay contest folder, Frederick Dickson, "Rex," 7.

37 Mechanics' Institutes and the Best Means of Improving Them, 8-9.

38 AMIO, AO, MU 2021, prize essay contest folder, John Davy, "Suum Cuique," 3 and Mechanics' Institutes and the Best Means of Improving Them, 16-17.

39 See the evening class statistics in the TMI, MTL, L1, series D, vols. 13-15, evening class rolls from 1877-1880. For the haphazard way secondary schools were established for youth during this period in Ontario, see the seminal work of R.D. Gidney and W.P.J. Millar, Inventing Secondary Education: The Rise of the High School in Nineteenth-Century Ontario, (Toronto: University of Toronto Press, 1990).

40 Barrie Mechanics' Institute fonds, Simcoe County Archives, B3 R4A S1 Sh5, minute book, 1871-1884, 2 and 29 October 1879.

41 Peterborough Mechanics' Institute fonds (hereafter PMI), National Library and Archives (hereafter NLA), series E2, leaflets and broadsides, E2:f:18, 10 September 1875 . 
42 On the importance of the "self-employed entrepreneur" in the Ontario economy, see David Burley, A Particular Condition in Life: Self-Employment and Social Mobility in Mid-Victorian Brantford, Ontario, (Montreal and Kingston: McGill-Queen's University Press, 1994); Holman, A Sense of Their Duty, 28-49 and Kristofferson, Craft Capitalism, chapters 1 and 2.

43 See the TMI, MTL, L1, series D, vols. 13-15, evening class rolls from 1877-1880.

44 See the PMI, NLA, series C, C:f:12, Correspondence of the Board, G.E. Shaw to W.E. Trout, 28 December 1878.

45 Peter Baskerville argues that the late nineteenth century saw an exponential growth in familial and individual business opportunities for the female gender; see his $A$ Silent Revolution? Gender and Wealth in English Canada, 1860-1930, (Montreal and Kingston: McGill-Queen's University Press, 2008), 222-35.

46 AMIO, AO, vol. 1, annual reports, twelfth annual meeting of the Association, speech of James Young, 22 September 1880, 8-11.

47 For the statistics of students enrolling in evening classes of Mechanics' Institutes compiled by the Association, see Foster, "The Development of Adult Education," 505.

48 For the importance of the Free Library movement in promoting the irrelevancy of urban Mechanics' Institutes by 1883, see Lorne Bruce, Free Books for All: The Public Library Movement in Ontario, 1850-1930, (Toronto: Dundurn Press, 1994), 94-117.

49 Foster, "The Development of Adult Education," 505. On the significance of establishing the Ontario School of Art, see Ramsay, "Art in Industrial Society," 96-7.

50 May, Special Report, 39-41, 68.

51 See the AMIO, AO, vol. 1, annual reports, seventeenth annual meeting of the Association, 15 September 1885.

52 AMIO, AO, vol. 1, annual reports, seventeenth annual meeting of the Association, 15 September 1885.

53 PMI, NLA, series A1, correspondence, A:f:21, letter from George Ross, 3 September 1886.

54 AMIO, AO, vol. 1, annual reports, eighteenth annual meeting of the Association, 14 September 1886.

55 AMIO, AO, vol. 1, annual reports, eighteenth annual meeting of the Association, 14 September 1886. On the increase of chartered Mechanics' Institutes after 1886, see Foster, "The Development of Adult Education," 489-90 and Ferry, Uniting in Measures of Common Good, 62-3. See also Walker, "The Yorkshire Union Has Grown," 136-39.

56 See Foster, "The Development of Adult Education," 505, 509-11 and Zeller, "Roads Not Taken." On the continuing importance of rural Mechanics' Institutes in Ontario in the latter half of the nineteenth century, see Holman, A Sense of Their Duty, 105-29 and Ferry, Uniting in Measures of Common Good, 74-94.

57 Foster, "The Development of Adult Education," 505.

58 Foster, "The Development of Adult Education," 505 and 511.

59 Ontario Department of Education (hereafter ODE), AO, MS-5635, subject files, RG 2-42-0-2271, report of A.H. Manning to George Ross, 1887, 13-15, 23-4.

60 For the debates over technical/vocational training offered in Ontario's schools see Zeller, "The Road not Taken," 14-16 and Robert Stamp, The Schools of Ontario: 1876-1976, (Toronto: University of Toronto Press, 1982), 57-59.

61 On this theme, see O.P. Rafferty, "Apprenticeship's Legacy: The Social and Educational Goals of Technical Education in Ontario, 1860-1911," (PhD diss., McMaster University, 1995).

62 On how the farming population participated in late nineteenth-century middle-class formation, see the seminal article by Gordon Darroch, "Scanty Fortunes and Rural Middle Class Formation in Nineteenth Century Rural Ontario," Canadian Historical Review 79, no. 4, (December, 1998): 621-59. 
63 The challenge to educating "adult" young women at the turn of the century was similar to that of the young men. See Nancy Jackson and Jane Gaskell, "White-Collar Vocationalism: The Rise of Commercial Education in Ontario and British Columbia, 1870-1920," Curriculum Inquiry 17, no. 2, (Summer 1987): 177-201; Ivor Goodson and Ian Dowbiggin, "Vocational Education and School Reform: The Case of the London Technical School," History of Education Review 20/1, (1991): 39-60 and Zeller, "Roads Not Taken."

64 PMI, NLA, series E2, leaflets and broadsides, E2:f:19, 1895/96.

65 See the Act and Regulations Respecting Public Libraries, Reading Rooms, Evening Classes and Art Schools, (Toronto: Warwick Bros., 1895), 4-5 and Bruce, Free Books for All, 105-113.

66 For the statistics on high school attendance in Ontario see Stamp, The Schools of Ontario, 40 and 280; for an advanced discussion on the increase of attendance in schools generally in English Canada for those aged 15 and 17 years see R.D. Gidney and W.P.J. Millar, How Schools Worked: Public Education in English Canada, 1900-1940, (Montreal and Kingston: McGill-Queen's University Press, 2012), 12-15 and 29-32. For a discussion on the changes in vocational/technical training in Ontario by 1911, see Stamp, The Schools of Ontario, 57-59, 82 and Bruce, Free Books for All, 145.

67 ODE, AO, MS-5635, subject files, RG 2-42-0-2287, Ottawa Technical Library report, 17 September 1901.

68 ODE, AO, MS-5635, subject files, RG 2-42-0-2287, Ottawa Technical Library report, letter of S.E. Cross, 29 October 1901. Similar conflicts between labour and capital, and employers and employees would take place during the establishment of the Toronto Technical School in 1892. See Zeller, “Roads Not Taken,” 17-20. 